\title{
Kejadian Obat-Obatan Penginduksi Kerusakan Liver pada Pasien Sirosis Rawat Inap di RSUD Dokter Soedarso Kalimantan Barat
}

(Drug-induced liver injury (DILI) in hospitalized patients with cirrhosis at Soedarso provincial hospital Kalimantan Barat)

\author{
Robiyanto $^{1 *}$, Jesica Liana ${ }^{2}$, \& Nera Umilia Purwanti ${ }^{2}$ \\ ${ }^{1}$ Departemen Farmakologi dan Farmasi Klinik Program Studi Farmasi Fakultas Kedokteran Universitas Tanjungpura \\ Pontianak, Bansir Laut, Kec. Pontianak Tenggara, Kota Pontianak, Kalimantan Barat \\ ${ }^{2}$ Program Studi Farmasi Fakultas Kedokteran Universitas Tanjungpura Pontianak, Bansir Laut, Kec. Pontianak \\ Tenggara, Kota Pontianak, Kalimantan Barat
}

\begin{abstract}
The potency of hepatotoxicity due to medication use is a risky clinical problem. This risk may aggravate the liver disease in a patient who already has a liver impairment condition. The aim of our research was to determine the most potential drug-induced liver injury (DILI) and the percentage of prescription drugs based on its Likelihood Score (category A,B,C,D,E, E* , X). This study was an observational descriptive with a cross-sectional design. Data retrieval was collected retrospectively using medical records of hospitalized cirrhosis patients in 2017. 36 patients who met inclusion criteria were involved as data sample. All data were analyzed using LiverTox database (https://livertox.nih.gov/) to categorize the Likelihood Score of each drug. The results of this study showed that the most prescribed drug which induce liver injury in cirrhosis patients were paracetamol (category $A)$, ranitidine $(B)$, cetirizine $(C)$, spironolactone $(D)$, furosemide $(E)$, and ketorolac $(E *)$. The percentage of prescription drugs for Likelihood Scores category $A=1,7 \% ; B=11,6 \% ; C=0,4 \% ; D=13,7 \% ; E=23,6 \% ; E^{*}=3,4 \%$ and $X=32,2 \%$. It can be concluded that the prescription of drugs which potentially induced liver injury (category A. B. C. D. E. E*) in cirrhosis patients at Soedarso Provincial Hospital Pontianak is quite high (54.4\%) and needs careful clinical consideration.
\end{abstract}

Keywords: DILI; Likelihood Score; LiverTox; prescription; cirrhosis.

ABSTRAK: Potensi terjadinya hepatotoksisitas karena penggunaan obat merupakan masalah klinis yang perlu diperhatikan. Risiko ini dapat menyebabkan bertambah parahnya penyakit liver yang diderita oleh pasien dengan riwayat penyakit liver tertentu. Penelitian ini bertujuan untuk menentukan jenis obat yang berpotensi menginduksi kerusakan liver atau drug-induced liver injury (DILI) dan persentase peresepan obat berdasarkan kategori Likelihood Scores (A, B, C, D, E, E*, X). Penelitian ini merupakan penelitian observasional deskriptif dengan desain potong lintang. Pengambilan data dilakukan secara retrospektif melalui rekam medik pasien sirosis rawat inap tahun 2017. Sebanyak 36 pasien sirosis memenuhi kriteria inklusi sebagai sampel penelitian. Analisa data menggunakan LiverTox database (https://livertox.nih.gov/) untuk mengetahui kategori Likelihood Score dari masingmasing obat. Hasil penelitian menunjukkan jenis obat yang paling banyak diresepkan dan berpotensi menginduksi kerusakan liver adalah parasetamol (kategori A), ranitidin (B), cetirizin (C), spironolakton (D), furosemid (E), dan ketorolak (E*). Persentase peresepan obat berdasarkan Likelihood Score kategori $A=1,7 \% ; B=11,6 \% ; C=0,4 \% ; D=13,7 \% ; E=23,6 \% ; E *=3,4 \%$ dan $X=32,2 \%$. Dapat disimpulkan bahwa peresepan obat yang berpotensi menginduksi keparahan fungsi liver (kategori $\left.A, B, C, D, E, E^{*}, X\right)$ pada pasien sirosis rawat inap di RSUD dr. Soedarso Pontianak masih tergolong tinggi (54.4\%) dan memerlukan pertimbangan klinis yang serius.

Kata kunci: DILI; Likelihood Score; LiverTox; peresepan; sirosis.

\section{Pendahuluan}

Sirosis adalah penyakit liver kronis/ menahun yang ditandai dengan proses peradangan dan nekrosis (kerusakan) sel liver [1]. Sirosis menempati urutan ke-7 sebagai penyebab kematian di Amerika diperkirakan sekitar 5,5 juta orang ( $2 \%$ populasi Amerika) menderita sirosis yang dikarenakan konsumsi alkohol [2]. Data prevalensi di Asia Tenggara diperkirakan $>70 \%$ penduduknya terinfeksi virus hepatitis B dan sekitar $20 \%$ berkembang menjadi sirosis [3]. Di Indonesia, sekitar 28 juta penduduk diperkirakan mengalami sirosis [4]. Penyebab utama sirosis di Indonesia adalah hepatitis B (40\%$50 \%)$ dan hepatitis C $(30 \%-40 \%)$ [5]. Menurut penelitian Tambunan dan Simamora di RSUD dr. Soedarso Pontianak menyatakan

\section{Article history}

Received: 28 Des 2019 Accepted: 29 Des 2019 Published: 30 Des 2019

Access this article

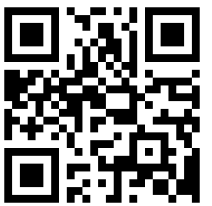


bahwa pasien sirosis terus meningkat dari tahun 20082012 dengan laju mortalitas sebesar 17.48\% [6, 7].

Salah satu penyebab timbulnya penyakit liver akut dan kronis adalah obat-obat penginduksi kerusakan liver/ drug induced liver injury (DILI) atau bersifat hepatotoksik [8]. Hepatoksisitas yang diakibatkan oleh obat merupakan masalah klinis yang sangat berisiko. Kondisi ini dapat mempengaruhi proses metabolisme hepar [9]. Obatobatan yang dapat menginduksi kerusakan hepar antara lain ranitidin. sefriakson. spironolakton. furosemid. dan parasetamol [10]. Contoh obat yang paling banyak diresepkan pada pasien sirosis adalah ranitidin [11]. Hal ini menunjukkan bahwa pasien gangguan fungsi hepar mendapatkan obat penginduksi kerusakan hepar [10]. Dampak yang terjadi ketika sel-sel hepar mengalami sirosis adalah munculnya komplikasi antara lain hipertensi portal, ascites, spontaneous bacterial peritonitis (SBP), verises esofagus, dan ensefalopati hepatik [12].

Tingginya penggunaan obat bersifat hepatotoksik pada pasien sirosis mendorong peneliti melakukan penelitian agar dapat mengidentifikasi jenis obat-obatan yang seharusnya tidak diberikan pada penderita sirosis. Penelitian ini dilakukan dengan mengumpulkan data peresepan obat pada pasien sirosis rawat inap. Harapan ke depannya agar pasien sirosis terhindar dari peresepan obat yang berpotensi memperparah fungsi organ heparnya (hepatotoksik).

\section{Metode Penelitian}

Penelitian ini merupakan penelitian observasional potong lintang dengan analisa deskriptif. Pengambilan data peresepan menggunakan rekam medik pasien sirosis rawat inap di RSUD dokter Soedarso Pontianak Kalimantan Barat tahun 2017. Subjek penelitian dipilih dengan kriteria inklusi berikut: pasien rawat inap dengan diagnosa sirosis $(\mathrm{ICD}=\mathrm{K} 74.6)$, pasien dirawat inap antara Januari Desember 2017, dan pasien menerima pengobatan selama rawat inap. Kriteria eksklusi meliputi pasien sirosis berusia $<18$ tahun, pasien sirosis pulang paksa atau yang memiliki data rekam medis tidak lengkap atau hilang.

Data yang dikumpulkan berupa data karakteristik (jenis kelamin, usia, lama rawat inap, hasil laboratorium) dan data peresepan obat yang diterima pada pasien sirosis selama rawat inap (nama obat, rute pemberian). Data yang diperoleh disajikan secara deskriptif dalam bentuk tabel dan grafik. Nama obat yang diresepkan selanjutnya dicek kategori Likelihood Score-nya berdasarkan LiverTox database (https://livertox.nih.gov/) apakah masuk kategori A, B, C, D, E, E*, atau X. Kategori A merupakan obat yang paling merusak hepar dengan prevalensi lebih dari 50 kasus (already well known to cause liver injury) dan kategori X merupakan kategori obat paling aman terhadap fungsi hepar. Liver'Tox merupakan sumber data berbasis web yang menyediakan informasi terkini, akurat, dan mudah diakses tentang diagnosis, penyebab, frekuensi pola, dan manajemen cedera organ hepar [13].

\section{Hasil dan Diskusi}

Hasil penelitian menunjukkan bahwa jumlah pasien sirosis rawat inap di RSUD dokter Soedarso Pontianak Kalimantan Barat Tahun 2017 sebanyak 45 pasien. Pasien yang memenuhi kriteria inklusi sebanyak 36 pasien dan 9 pasien dimasukkan dalam kriteria eksklusi karena 1 pasien tidak tercantum data usianya dan sebanyak 8 pasien rekam medisnya hilang.

Tabel 1 menunjukkan bahwa laki-laki memiliki faktor resiko lebih tinggi menderita sirosis (69.4\%) dibandingkan perempuan $(30.6 \%)$. Penelitian sebelumnya oleh Hikmah [10] berdasarkan jenis kelamin didapatkan 61\% pasien laki-laki dan 39\% pasien perempuan serta penelitian Cahaya [11] didapatkan 38 berjenis kelamin laki-laki dan 34 berjenis kelamin perempuan dari 72 pasien gangguan fungsi hepar. Menurut Guy and Peters [14] laki-laki memiliki resiko kematian karena gangguan hepar 2X lebih tinggi dibandingkan perempuan. Alasan laki-laki rentan terkena penyakit liver karena memiliki kebiasaan merokok dan mengkonsumsi alkohol [15]. Menurut Lotter et al., tikus jantan rentan terkena penyakit liver karena adanya hormon testosteron. Hormon ini meningkatkan kerentanan amuba menyebabkan abses liver [16]. Berbeda dengan tikus jantan, tikus betina memiliki hormon esterogen yang dapat melindungi sel-sel hepar dan membantu proses regenerasi sel hepatik [16].

Pengelompokkan usia pasien sirosis pada Tabel 1 menunjukkan bahwa masa lansia memiliki persentase tertinggi yaitu 69,4\%. Hal ini dikarenakan semakin meningkatnya usia semakin menurun pula fungsi organ tubuh. Penurunan ini mengakibatkan fungsi organ tubuh tidak dapat bekerja secara maksimal serta dapat mempengaruhi organ lain dan memicu komplikasi [11]. Faktor yang mempengaruhi banyaknya pasien yang terkena penyakit hepar pada usia dewasa yaitu dikarenakan keturunan (genetik) serta faktor zat-zat toksik seperti obatobatan, alkohol dan gaya hidup tidak sehat yang meracuni hepar [15]. Dari Tabel 1 terlihat bahwa lama rawat inap pasien sirosis selama 7 hari dengan persentase $61,1 \%$. Penatalaksanaan pengobatan di rumah sakit untuk pasien sirosis dengan mengurangi progresi penyakit, menghindari 
bahan-bahan yang dapat menambah kerusakan hepar, dan juga penanganan komplikasi penyerta agar kualitas hidup pasien bisa dikontrol.

Tabel 2 menunjukkan nilai serum glutamic oxaloacetic transaminase (SGOT) dan serum glutamic pyruvic transaminase (SGPT) pada pasien sirosis. Sebanyak 22 dari 36 pasien mengalami peningkatan diatas normal (5-35 $\mu / \mathrm{L})$. Peningkatan SGOT dan SGPT disebabkan kerusakan dinding sel hepar sehingga digunakan sebagai penanda gangguan integritas sel hepatoseluler. Peningkatan enzim alanine transminase (ALT)/ SGPT dan aspartate transaminase (AST)/SGOT sampai $300 \mu / \mathrm{L}$ tidak spesifik untuk kelainan hepar saja. namun peningkatan lebih dari 1000 $\mu / L$ dapat dijumpai pada penyakit hepar akibat infeksi virus, iskemik hepar yang disebabkan hipotensi kronis atau gagal jantung akut, dan kerusakan hepar akibat obat atau zat toksik. Rasio AST/ALT dapat digunakan untuk melihat beratnya kerusakan sel hepar. Rasio AST/ALT $<0,8$ menandakan kerusakan hepar ringan dan rasio AST/ALT >0,8 menandakan kerusakan hepar berat atau kronis [24,25]. Hasil rasio nilai SGOT/SGPT pada lakilaki adalah 1,7 menunjukkan tingkat kerusakan hepar berat dan pada perempuan adalah 1,04 menujukkan kerusakan hepar berat juga.

Albumin merupakan protein utama yang dihasilkan oleh organ hepar. Kadar albumin akan menurun (hipoalbumin) jika terdapat gangguan fungsi hepar. Penyebab lain hipoalbumin selain gangguan fungsi hepar yaitu gagal ginjal, kerusakan kulit akibat luka bakar yang luas, dan kerusakan usus akibat malabsorbsi protein [26]. Hasil menunjukan bahwa terjadi penurunan kadar albumin dibawah rentang normal (3.5-5.0 $\mathrm{g} / \mathrm{dL}$ ) pada pria maupun wanita.

Tabel 1. Karakteristik Subyek Penelitian

\begin{tabular}{|c|c|c|c|c|}
\hline \multirow{2}{*}{ No. } & \multirow{2}{*}{\multicolumn{2}{|c|}{ Tipe Karakteristik }} & \multicolumn{2}{|c|}{$\mathrm{N}$ pasien $=36$} \\
\hline & & & Jumlah Pasien & Persentase (\%) \\
\hline \multirow[t]{2}{*}{1} & Jenis Kelamin & Pria & 25 & 69.4 \\
\hline & & Wanita & 11 & 30.6 \\
\hline \multirow[t]{3}{*}{2} & Usia (Tahun) & $26-45$ & 8 & 22.2 \\
\hline & & $46-65$ & 25 & 69.4 \\
\hline & & $>65$ & 3 & 8.3 \\
\hline \multirow[t]{3}{*}{3} & Lama Rawat Inap (Hari & $\leq 7$ & 22 & 61.1 \\
\hline & & $\leq 14$ & 13 & 36.1 \\
\hline & & $>14$ & 1 & 2.8 \\
\hline
\end{tabular}

Tabe1 2. Hasil Pemeriksaan Fungsi Liver Pasien Sirosis

\begin{tabular}{ccccc}
\hline No. & & Jenis Pemeriksaan & Jumlah & Nilai Rata-rata $(\boldsymbol{\mu} / \mathbf{L})$ \\
\hline 1 & \multirow{2}{*}{ SGOT } & Pria & 15 & 80.77 \\
& & Wanita & 7 & 188.81 \\
2 & \multirow{2}{*}{ SGPT } & Pria & 15 & 48.49 \\
& & Wanita & 7 & 77.64 \\
3 & \multirow{2}{*}{ Albumin } & Pria & 11 & 2.61 \\
& & Wanita & 4 & 2.51 \\
4 & \multirow{2}{*}{ Bilirubun direk } & Pria & 8 & 4.00 \\
& & Wanita & 2 & 6.78 \\
\multirow{2}{*}{5} & \multirow{2}{*}{ Bilirubin total } & Pria & 8 & 6.58 \\
& & Wanita & 2 & 12.83 \\
\hline
\end{tabular}


Bilirubin berasal dari pemecahan heme akibat penghancuran sel darah merah oleh sel retikuloendotel. Kadar albumin pada prehepatik akan meningkat dikarenakan penghancuran sel darah merah berlebihan $[23,26]$. Kadar bilirubin direk pada pria dan wanita menunjukkan bahwa terjadi peningkatan kadar dibatas normal $(<0.4 \mathrm{mg} / \mathrm{dL})$. Peningkatan kadar di batas normal $(<1.4 \mathrm{mg} / \mathrm{dL})$ juga terjadi pada bilirubin total pria dan wanita.

Penggunaan obat-obatan yang diterima pasien sirosis secara keseluruhan dapat dilihat pada Tabel 3. Tabel 3 menunjukkan bahwa penggunaan kelas terapi terbanyak yaitu antibiotik. Antibiotik dipilih sebagai terapi berdasarkan penyakit penyerta yang dialami pasien [10]. Penggunaan antibiotik yang paling banyak adalah sefotaksim (52,8\%). Sefotaksim merupakan antibiotik golongan sefalosporin generasi III. Selain sefotaksim, sefiksim dan sefriakson juga termasuk golongan sefalosporin generasi III. Kelas terapi kedua yang banyak digunakan yaitu analgesik non narkotik, antitukak dan hepatoprotektor. Jenis obat yang banyak digunakan pada analgesik non narkotika yaitu ketorolac (22.2\%), antitukak yaitu ranitidin $(52.8 \%)$. dan hepatoprotektor yaitu curcuma (55.6\%). Umumnya. penyakit hepar menimbulkan gejala lemas dan lelah sehingga multivitamin/mineral/suplemen sangat diperlukan sebagai terapi penunjang bagi pasien sirosis. Pasien sirosis juga diberikan terapi antihipertensi golongan diuretik. Tujuan dari pemberian diuretik ini untuk mengurangi edema pada kaki, rongga perut, dan lainnya. Kelas terapi lainnya ialah antidiabetik, antiemetik, antimigran, antivirus, dan lain-lainnya digunakan untuk mengurangi atau mengobati penyakit tambahan dan berbagai keluhan yang dialami pasien sirosis.

Tabel 3. Distribusi Peresepan Obat pada Pasien Sirosis Rawat Inap

\begin{tabular}{|c|c|c|c|c|c|}
\hline No. & Kelas Terapi & Jenis Obat & Rute & $\begin{array}{l}\text { Jumlah Pasien } \\
\text { Menerima Obat }\end{array}$ & $\begin{array}{c}\text { Persentase Pasien Yang } \\
\text { Menerima Obat ( } \mathrm{N} \text { pasien=36) }\end{array}$ \\
\hline \multirow[t]{6}{*}{1} & Hepatoprotektor $(\mathrm{N}=\mathbf{3 1}$ ) & Curcuma & $\mathrm{PO}$ & 20 & 55.6 \\
\hline & & SNMC & IV/PO & 5 & 13.9 \\
\hline & & Hepamax ${ }^{\circledast}$ & IV/PO & 2 & 5.6 \\
\hline & & Hepa Merz ${ }^{\circledR}$ & IV & 2 & 5.6 \\
\hline & & $\mathrm{AHFC}^{\circledast}$ & $\mathrm{PO}$ & 1 & 2.8 \\
\hline & & Aminofusin hepar & IV & 1 & 2.8 \\
\hline \multirow[t]{6}{*}{2} & Analgesik non opioid & Ketorolak & IV & 8 & 22.2 \\
\hline & & Sistenol ${ }^{\circledR}$ & PO & 2 & 5.6 \\
\hline & & As. Mefenamat & PO & 1 & 2.8 \\
\hline & & Parasetamol & $\mathrm{PO}$ & 1 & 2.8 \\
\hline & & Meloxicam & PO & 1 & 2.8 \\
\hline & & Dexamethason & IV & 3 & 8.3 \\
\hline 3 & Analgesik opioid & Tramadol & IV & 2 & 5.6 \\
\hline \multirow[t]{6}{*}{4} & Antitukak/antiulser & Ranitidin & IV & 19 & 52.8 \\
\hline & & Sukralfat & $\mathrm{PO}$ & 11 & 30.6 \\
\hline & & Omeprazol & IV & 7 & 19.4 \\
\hline & & Lansoprazol & PO & 5 & 13.9 \\
\hline & & Panso ${ }^{\circledR}$ & IV & 1 & 2.8 \\
\hline & & Rebamipid & PO & 1 & 2.8 \\
\hline \multirow[t]{4}{*}{5} & Antibiotik & Sefotaksim & IV/PO & 19 & 52.8 \\
\hline & & Metronidazol & IV & 5 & 13.9 \\
\hline & & Sefriakson & IV & 3 & 8.3 \\
\hline & & Siprofloksasin & PO & 1 & 2.8 \\
\hline
\end{tabular}




\begin{tabular}{|c|c|c|c|c|c|}
\hline & & Fosmicin ${ }^{\circledast}$ & IV & 1 & 2.8 \\
\hline & & Neomisin & PO & 1 & 2.8 \\
\hline & & Sefazolin & IV & 1 & 2.8 \\
\hline & & Sefiksim & $\mathrm{PO}$ & 1 & 2.8 \\
\hline & & Tyason ${ }^{\circledast}$ & IV & 1 & 2.8 \\
\hline \multirow[t]{3}{*}{6} & Antidiabetik & Glikuidon & PO & 1 & 2.8 \\
\hline & & Glurenorm & PO & 1 & 2.8 \\
\hline & & Novorapid $^{\circledR}$ & SC & 1 & 2.8 \\
\hline \multirow[t]{2}{*}{7} & Antiemetik & Ondansentron & IV & 6 & 16.7 \\
\hline & & Domperidon & PO & 1 & 2.8 \\
\hline \multirow[t]{3}{*}{8} & Antihipertensi & Furosemid & IV/PO & 25 & 69.4 \\
\hline & & Spironolakton & PO & 23 & 63.9 \\
\hline & & Propanolol & PO & 10 & 27.8 \\
\hline 9 & Antifibrinolitik & Kalnex ${ }^{\circledast}$ & IV & 5 & 13.9 \\
\hline 10 & Antimigran & Vastigo ${ }^{\oplus}$ & $\mathrm{PO}$ & 1 & 2.8 \\
\hline \multirow[t]{4}{*}{11} & Antivirus & Myhep ${ }^{\circledR}$ & IV & 1 & 2.8 \\
\hline & & Ribavirin & IV & 1 & 2.8 \\
\hline & & Sebivo ${ }^{\circledast}$ & IV & 1 & 2.8 \\
\hline & & Lamivudin & $\mathrm{PO}$ & 1 & 2.8 \\
\hline 12 & Antialergi & Cetirizin & PO & 1 & 2.8 \\
\hline 13 & Antiangina & ISDN & $\mathrm{PO}$ & 2 & 5.6 \\
\hline 14 & Ekspektoran & Ambroksol & $\mathrm{PO}$ & 1 & 2.8 \\
\hline 15 & Kolagoga & Urdafalk ${ }^{\circledast}$ & PO & 2 & 5.6 \\
\hline \multirow[t]{3}{*}{16} & Laksatif & Lactulax ${ }^{\circledast}$ & $\mathrm{PO}$ & 1 & 2.8 \\
\hline & & Prolaxan $^{\circledast}$ & $\mathrm{PO}$ & 1 & 2.8 \\
\hline & & Pralax $^{\circledast}$ & $\mathrm{PO}$ & 1 & 2.8 \\
\hline \multirow[t]{6}{*}{17} & $\begin{array}{l}\text { Multivitamin/mineral/ } \\
\text { suplemen }\end{array}$ & Vitamin K & IV & 13 & 36.1 \\
\hline & & Vip Albumin & PO & 3 & 8.3 \\
\hline & & Asam Folat & PO & 2 & 5.6 \\
\hline & & Albuforce ${ }^{\circledast}$ & PO & 1 & 2.8 \\
\hline & & KSR & PO & 1 & 2.8 \\
\hline & & & Total Peresepan Obat & 233 & \\
\hline
\end{tabular}

Jenis hepatoprotektor yang diresepkan kepada pasien sirosis sebanyak 6 jenis dengan total 31 peresepan. 7 dari 36 pasien sirosis dalam penelitian ini tidak mendapatkan hepatoprotektor (Tabel 4). Penggunaan obat yang masuk dalam kategori A, B, C, D, E, E*, X yang diterima pasien sirosis sebanyak 202 obat (Tabel 5) dari total 233 jumlah peresepan obat (Tabel 3 ). Berdasarkan data Tabel 3 dan $\underline{5}$ didapatkan persentase penggunaan obat berpotensi DILI (kategori A, B, C, D, E, E*) yang diterima oleh pasien sirosis sebanyak $54,4 \%$.

Tabel 5 menunjukkan bahwa penggunaan parasetamol dikategorikan A karena parasetamol diketahui pasti bersifat hepatotoksik akut terutama pada penggunaan dosis besar. Terapi parasetamol diketahui dapat menyebakan cedera hepatoseluler akut dan serius akibat dari overdosis yang disengaja atau tidak disengaja. 
Cedera ini disebabkan oleh efek toksik langsung dari parasetamol dosis tinggi. Hepatotoksisitas paling umum muncul sebagai upaya bunuh diri menggunakan lebih dari 7,5 gram (umumnya lebih dari 15 gram) sebagai overdosis tunggal [13]. Sistenol ${ }^{\circledR}$ mengandung zat aktif parasetamol sebagai antipiretik dan analgesik dan asetilsitein untuk mengencerkan dahak. Adanya kombinasi asetilsistein dengan parasetamol telah dilaporkan jarang menimbulkan

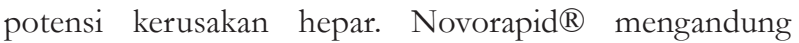
zat aktif insulin dimana penggunaan dosis terapeutik tidak meningkatan enzim serum. Namun. penggunaan insulin pada diabetes tipe 1 yang tidak terkontrol dapat menyebabkan sindrom klinis yang dikenal sebagai glikogenosis atau hepatopati glikogenik dan ditandai dengan berbagai tingkat hepatomegali, nyeri perut, dan peningkatan serum aminotransferase serum [13].

Pasien rawat inap biasanya mengalami hipermetabolisme yang menyebabkan peningkatan sekresi asam lambung sehingga diperlukan obat yang mampu menekan sekresi asam lambung seperti ranitidin, omeprazol dan obat sejenis lainnya. Ranitidin merupakan antagonis reseptor $\mathrm{H} 2$ yang bekerja dengan menghambat histamin pada reseptor $\mathrm{H} 2$ secara kompetitif dan mengurangi sekresi asam lambung. Efek yang ditimbulakan ranitidin dapat meningkatkan nilai SGPT dan memperluas kerusakan hepar. Toksisitas ranitidin bersifat reversibel dan ringan akan tetapi pada kerusakan liver yang parah telah menyebabkan kematian beberapa individu [17].

Tabel 4. Persentase Peresepan Hepatoprotektor pada Pasien Sirosis

\begin{tabular}{cccc}
\hline Nama Obat & Rute & $\begin{array}{c}\text { Jumlah Pasien } \\
\text { Menerima Obat }\end{array}$ & $\begin{array}{c}\text { Persentase Pasien Yang Menerima } \\
\text { Obat (N pasien=36) }\end{array}$ \\
\hline Curcuma & PO & 20 & 55.6 \\
SNMC & IV/PO & 5 & 13.9 \\
Hepamax $^{\circledast}$ & IV/PO & 2 & 5.6 \\
Hepa Merz & IV & 2 & 5.6 \\
AHFC $^{\circledast}$ & PO & 1 & 2.8 \\
Aminofusin hepar & IV & 1 & 2.8 \\
Total Peresepan Obat & & $\mathbf{3 1}$ & \\
\hline
\end{tabular}

Keterangan: SNMC = Stronger Neo Minophagen C; AHFC = Anti Hepatic Fibrosis Cirrhosis PO = peroral ; IV $=$ intravena

Tabel 5. Distribusi Peresepan Drug-Induced Liver Injury (DILI) berdasarkan Kategori Likelihood Scores pada Pasien Sirosis

\begin{tabular}{|c|c|c|c|c|}
\hline Likelihood Scores & Nama Obat & Efek Penggunaan Obat & $\begin{array}{l}\text { Jumlah } \\
\text { Peresepan } \\
\text { Obat }\end{array}$ & $\%(N=233)$ \\
\hline \multirow[t]{2}{*}{$\begin{array}{c}\text { A } \\
\text { (well known) }\end{array}$} & Sistenol ${ }^{\circledast}$ & 个 kadar ALT selama terapi. hipersensitifitas & 2 & 1.7 \\
\hline & $\begin{array}{l}\text { Parasetamol } \\
\text { Novorapid }^{\circledR}\end{array}$ & $\begin{array}{l}\text { 个 serum aminotransferase. hepatoseluler akut } \\
\text { 个 serum aminotransferase. ALT \& AST }\end{array}$ & $\begin{array}{l}1 \\
1\end{array}$ & \\
\hline \multirow[t]{2}{*}{$\begin{array}{c}\text { B } \\
\text { (known or highly } \\
\text { likely) }\end{array}$} & Ranitidin & Imunoalergik hepatitis kolestatik & 19 & 11.6 \\
\hline & $\begin{array}{l}\text { Omeprazol } \\
\text { Siprofloksasin }\end{array}$ & $\begin{array}{l}\text { 个 minor kadar serum aminotransferase } \\
\text { Reaksi hipersensitivitas. } \text { 个ALT jangka panjang }\end{array}$ & 7 & \\
\hline $\begin{array}{c}\text { C } \\
\text { (probably) }\end{array}$ & Cetirizin & 个 enzim liver jangka panjang. Cedera Idiosinkratik & 1 & 0.4 \\
\hline \multirow[t]{3}{*}{$\begin{array}{c}\text { D } \\
\text { (possible) }\end{array}$} & Spironolakton & $\uparrow$ enzim serum biasanya hepatoseluler/campuran & 23 & 13.7 \\
\hline & Ondansetron & $\uparrow$ enzim serum aminotrasferase & 6 & \\
\hline & Urdafalk ${ }^{\circledR}$ & - & 2 & \\
\hline
\end{tabular}




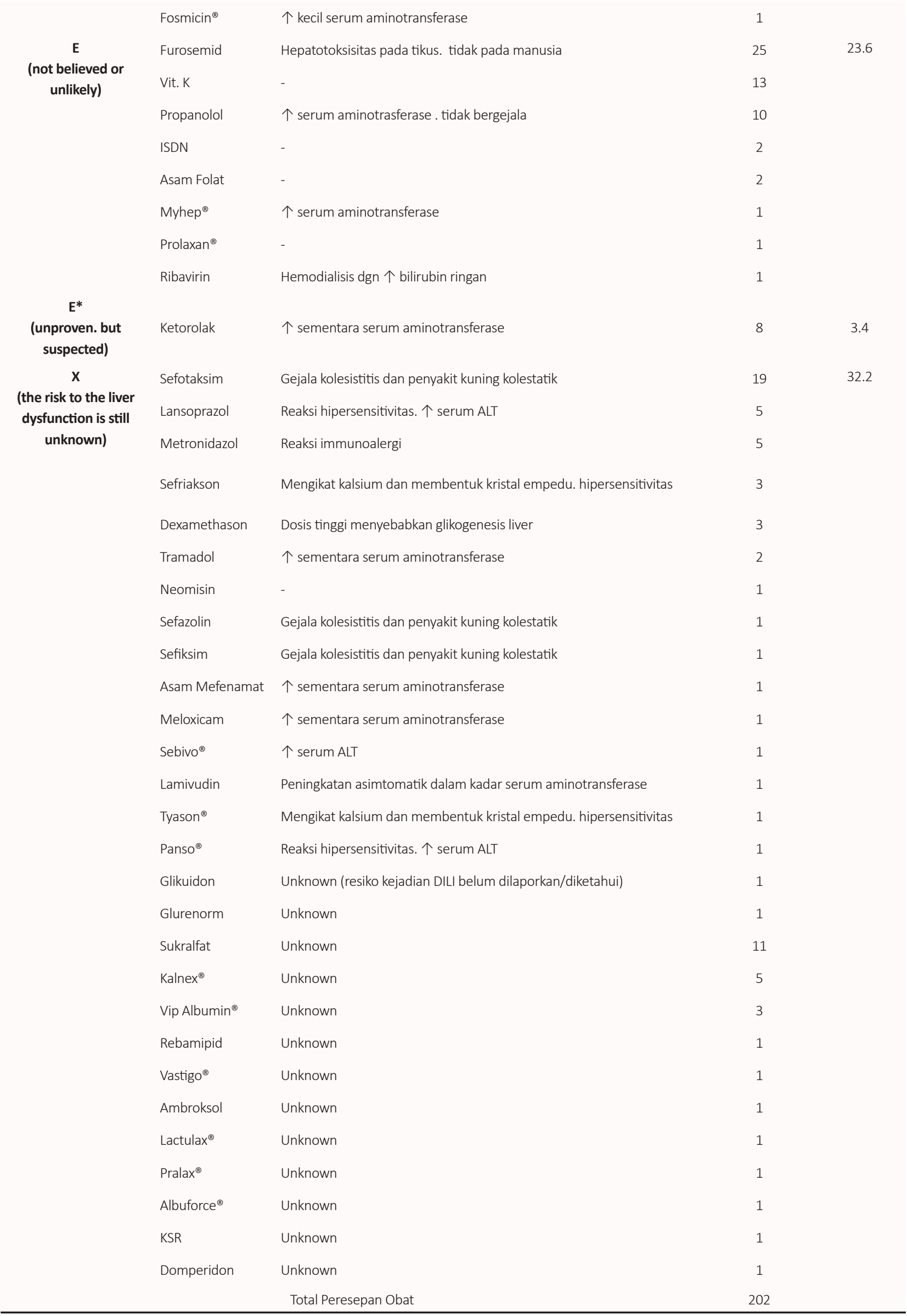


Terapi omeprazol menimbulkan cidera hepar dengan reaksi hipersensitivitas yang dicurigai akibat perubahan metabolisme. Obat tersebut dimetabolisme oleh sistem P450 (CYP2C19) hepar tetapi memiliki sedikit efek pada aktivitas enzim yang memetabolisme obat. Penggunaan obat dalam 4 minggu akan muncul cedera hepatoseluler akut dan akan pulih setelah berhenti pemakaian (reversibel). Ciprofloxacin telah dikaitkan dengan kasus cedera hepar akut yang jarang tetapi kadang-kadang parah dan bahkan fatal. Peningkatan enzim serum selama terapi ciprofloxacin masih rendah. Pola peningkatan enzim serum dapat berupa hepatoseluler atau kolestatik. Penggunaan cetirizine umumnya tidak berhubungan dengan peningkatan enzim liver tetapi terdapat kasus yang jarang dari cedera liver yang tampak secara klinis. Kasus-kasus yang dilaporkan adalah keparahan ringan sampai sedang dan sembuh sendiri dengan pemulihan cepat setelah menghentikan pengobatan [13].

Spironolakton menjadi peringkat kedua terbanyak setelah furosemid. Spironolakton dan furosemid digunakan untuk mengatasi udema. Menurut data LiverTox cedera hepar yang tampak secara klinis dari spironolakton jarang terjadi dan hanya beberapa kasus yang dilaporkan sebagai laporan khusus yang terisolasi. Namun cedera hepar akan muncul setelah 4-8 minggu dengan peningkatan enzim serum biasanya hepatoseluler atau campuran [13]. Menurut Hikmah, pasien sirosis yang mendapatkan terapi spironolakton bersamaan obat diuretik lainnya dapat memperparah ensefalopati hepar [10]. Walaupun begitu spironolakton dapat digunakan sebagai tata laksana terapi untuk penyakit komplikasi sirosis dengan catatan bahwa penurunan dosis serta dilakukan pemantauan dan pengawasan kadar obat [18]. Ondansetron merupakan antagonis reseptor 5-HT3 dapat meningkatkan enzim serum sesekali selama terapi tetapi ini umumnya ringan (tanpa gejala) dan sembuh dengan cepat. Permulaan cedera mulai 1 hingga 2 minggu setelah paparan dan pola cedera hepatoseluler dan tanpa fitur immunoalergi atau autoimun. Blocker reseptor 5-HT3 dimetabolisme di liver sebagian besar melalui sistem sitokrom P450 tetapi potensinya rendah untuk menyebabkan cedera hepar [13].

Beberapa uji klinis urdafalk ${ }^{\circledR}$ belum ditemukan dapat menyebabkan peningkatan enzim serum dan memburuknya penyakit hepar. Urdafalk mungkin berbahaya pada pasien dengan penyakit hepar lanjut. Penyebab langka dari memburuknya penyakit hepar selama penggunaan urdafalk kemungkinan disebabkan oleh koleresis (peningkatan aliran empedu) yang merangsang bukan pada reaksi intrinsik atau idiosinkratik terhadap obat itu sendiri. Fosmisin ${ }^{\circledR}$ menyebabkan cedera ringan dan terbatas dan tidak ada kasus gagal hepar akut yang fatal, hepatitis kronis atau sindrom saluran empedu yang hilang [13].

Hepatotoksik furosemid sangat jarang terjadi. namun furosemid dapat menyebabkan hepatotoksik langsung pada tikus. Hasil data yang diperoleh. furosemid diberikan dalam bentuk injeksi sebanyak 17 pasien dan 8 pasien dalam bentuk oral. Vitamin $\mathrm{K}$ dalam dosis normal maupun berlebihan tidak terjadi peningkatan ALT atau cedera hepar yang tampak secara klinis. Vitamin $\mathrm{K}$ diambil dan disimpan di liver tetapi tidak mengalami metabolisme oleh sistem sitokrom P450. Propranolol mengalami metabolisme jalur cepat pertama oleh hepar tetapi memiliki sedikit atau tidak ada efek pada aktivitas P450. Alasan mengapa jarang menyebabkan cedera hepar tidak diketahui. Isosorbid dinitrat (ISDN) telah digunakan secara luas selama beberapa dekade tidak menyebabkan peningkatan enzim serum atau cedera hepar yang tampak secara klinis. Asam folat pada dosis normal atau terlalu tinggi tidak menyebabkan cedera hepar atau kelainan fungsi hepar. Penggunaan asam folat dosis tinggi (hingga $15 \mathrm{mg}$ setiap hari) belum dikaitkan dengan efek samping yang cukup besar. peningkatan ALT atau hepatotoksisitas. Asam folat disimpan di hepar tetapi dimetabolisme di banyak jaringan dan tidak memiliki efek pada sistem enzim mikrosom hepar [13].

Myhep ${ }^{\circledR}$ dengan komposisi sofosbuvir merupakan obat untuk mengobati penyakit hepar kronis seperti hepatitis. Namun terapi myhep ${ }^{\circledR}$ dapat meningkatkan serum dengan cepat yaitu peningkatan ALT yang terlambat $>3$ kali batas normal. Myhep ${ }^{\circledR}$ dimetabolisme di liver sebagian besar melalui sistem sitokrom P450, terutama CYP1A2. Prolaxan ${ }^{\circledR}$ memiliki kandungan bisakodil yang bertujuan untuk mengatasi sembelit atau konstipasi. Bisakodil belum dikaitkan dengan peningkatan enzim serum selama terapi atau dengan kejadian cedera hepar yang tampak secara klinis. Ribavirin biasanya digunakan pada pasien dengan penyakit hepar yang seperti hepatitis C dimana sulit untuk menafsirkan peningkatan kadar ALT serum selama terapi. dan biasanya ribavirin menurunkan kadar ALT serum pada pasien tersebut. Ribavirin dimetabolisme minimal oleh hepar dan diekskresikan sebagian besar dalam bentuk tidak berubah oleh ginjal. Ini mungkin merupakan penyebab tidak adanya atau jarangnya terjadi cedera hepar. Hiperbilirubinemia yang terkait dengan penggunaan ribavirin disebabkan oleh hemolisis sel darah merah dan produksi bilirubin yang berlebihan [13].

Ketorolac selain digunakan sebagai obat penurun panas dan nyeri juga bisa sebagai pencegah pembentukan 
gumpalan darah (antiplatelet). Ketorolac tidak terbukti tetapi diduga sebagai penyebab cedera hepar yang nyata secara klinis [13].

Sefotaksim, sefriakson, sefazolin, dan sefiksim merupakan antibiotik golongan sefalosporin. Antibiotik golongan sefalosporin dapat menyebabkan gejala kolesistitis dan penyakit kuning kolestatik. Lansoprazole jarang dikaitkan dengan cedera liver dan peningkatan serum ALT konsumsi jangka panjang telah terjadi pada < $1 \%$ pasien [13].

Lansoprazole menunjukkan reaksi hipersensitivitas tetapi mungkin hanya mencerminkan metabolisme yang berubah atau toksisitas akut dari produk sampingan metabolik. Lansoprazole dimetabolisme oleh sistem P450 tetapi memiliki sedikit efek pada aktivitas enzim yang memetabolisme obat. Metronidazole dosis tinggi yang diberikan secara parenteral atau overdosis dapat menyebabkan peningkatan kadar serum aminotransferase serum. Namun cedera hepar akut dan klinis dari metronidazole jarang terjadi. Penyebab cedera hepar akut akibat metronidazole mungkin immunoalergi [13].

Dexamethasone merupakan obat golongan kortikosteroid. Hepatotoksitas kortikosteroid secara umum memiliki efek besar pada hepar, terutama bila diberikan jangka panjang dan dalam dosis yang lebih tinggi. Kortikosteroid dapat memicu atau memperburuk steatohepatitis nonalkohol. Penggunaan jangka panjang juga dapat memperburuk hepatitis virus kronis. Terapi kortikosteroid dapat menyebabkan steatosis dan pembesaran hepar, tetapi ini sering tidak tampak secara klinis terutama pada orang dewasa. Konsumsi kortikosteroid pada hepatitis B dapat menginduksi peningkatan replikasi virus dan kadar DNA virus hepatisis B sekaligus menurunkan kadar serum aminotransferase. Namun, peningkatan replikasi virus dapat memperburuk penyakit hepar yang mendasarinya [13].

Tramadol dapat meningkatkan serum aminotransferase dan pada sebagian kecil pasien yang menerima tramadol. terutama dengan dosis tinggi. Cedera hepar yang disebabkan oleh overdosis tramadol juga telah dikaitkan dengan hiperammonemia, asidosis laktat dan steatosis hepar, menunjukkan cedera mitokondria langsung. Mekanisme hepatotoksisitas akibat overdosis tramadol tidak diketahui, tetapi kemungkinan karena cedera hepatoseluler langsung baik sebagai akibat iskemia atau toksisitas mitokondria. Tramadol dimetabolisme oleh liver terutama oleh CYP2D6 dan 3A4 menjadi bentuk aktifnya dan dapat mengakibatkan interaksi obat-obat yang merugikan. Neomisin belum diketahui meningkatkan aminotransferase. Buruknya absorpsi neomisin membuatnya tidak mungkin dapat menyebabkan cedera hepar. Studi prospektif asam mefenamat menunjukkan bahwa $<5 \%$ pasien yang menggunakan asam mefenamat mengalami peningkatan serum sementara aminotransferase. Peningkatan aminotransferase yang ditandai $>3$ kali lipat terjadi pada $<1 \%$ pasien. Mekanisme hepatotoksisitas asam mefenamat tidak diketahui tetapi kemungkinan hipersensitivitas istimewa. Meloxicam merupakan golongan NSAID (obat antiinflamasi non steroid) yang umumnya dapat ditoleransi dengan baik tetapi efek sampingnya bisa berupa gangguan pencernaan dan rasa sakit, mual, sakit kepala, pusing, mengantuk, gatal, edema perifer, dan reaksi hipersensitivitas. Studi prospektif menunjukkan bahwa hingga $7 \%$ pasien yang menggunakan meloxicam mengalami setidaknya peningkatan sementara serum aminotransferase. Mekanisme hepatotoksisitas meloxicam tidak diketahui [13].

Sebivo ${ }^{\circledR} \quad$ (telbivudin) diketahui diresepkan untuk pengobatan hepatitis B kronis. Tidak adanya hepatotoksisitas yang signifikan dari telbivudin mungkin karena kurangnya dimetabolisme hepar. Secara in vitro, telbivudine memiliki sedikit aktivitas melawan gamma mitokondria. Penghambatan yang telah terlibat dalam sindrom cedera mitokondria hepatik dengan asidosis laktat, steatosis, dan gagal liver. Lamivudin digunakan sebagai terapi HIV dan pada dosis kecil bisa untuk infeksi hepatitis B. Lamivudine adalah penyebab langka kelainan tes hepar atau cedera hepar yang tampak secara klinis pada pasien dengan infeksi HIV tanpa hepatitis B. Tyason ${ }^{\circledR}$ merupakan obat terapi sefriakson golongan sefalosporin. Hepatoksitas dari tyason ${ }^{\circledR}$ dapat dilihat pada terapi sefriakson. Panso ${ }^{\circledR}$ (pantoprazole) yang dikonsumsi jangka panjang jarang dikaitkan dengan cedera hepar. Onset akut dan kekambuhan cepat dari cedera hepar dengan pantoprazole menunjukkan reaksi hipersensitivitas tetapi mungkin hanya mencerminkan perubahan metabolisme pantoprazole dimetabolisme terutama oleh CYP2C19 dengan metabolisme yang lebih rendah dengan CYP3A4. Glikuidon dan glurenorm merupakan obat antidiabetik golongan sulfonilurea yang bertujuan menurunkan gula darah dengan meningkatkan pelepasan insulin dari pankreas. Hepatoksitas pada sulfonilurea jarang terjadi mungkin dikarenakan sedikit informasi yang belum memadai [13].

Potensi DILI suatu obat berdasarkan LiverTox database dibagi menjadi 7 kategori. Kategori A merupakan kategori obat yang menyebabkan kerusakan hepar langsung atau idiosinkratik dan dilaporkan lebih dari 50 kasus. Gambar 2 menunjukkan bahwa penggunaan obat kategori A sebesar 1,7\%. Kategori selanjutnya yaitu B 
dengan persentase sebesar 11,6\%. Obat yang masuk kategori ini dilaporkan dan diketahui sangat mungkin menyebabkan cedera hepar idiosinkratik yang sekitar 12 dan 50 kasus. Kategori penggunaan obat yang paling sedikit digunakan yaitu kategori $\mathrm{C}$ sebesar $0,4 \%$. Obat dalam kategori ini mungkin menyebabkan cedera hepar idiosinkratik tetapi telah dilaporkan secara tidak biasa dan tidak ada tanda karakteristik yang telah diidentifikasi. Jumlah kasus yang diidentifikasi kurang dari 12 tanpa seri kasus yang signifikan. Kategori D masuk dalam kategori penyebab kerusakan hepar langkah karena terdapat 3 kasus dilaporkan dalam literatur tetapi laporan kasus tidak menyakinkan. Penggunaan obat dalam kategori D sebesar 13,7\%. Kategori E adalah kategori dengan persentase kedua tertinggi sebesar 23,6\% setelah kategori X. Kategori E belum terbukti obat tersebut dapat menyebabkan kerusakan hepar. Kategori ini diyakini tidak menyebabkan kerusakan hepar. Obat dalam kategori $E^{*}(3,4 \%)$ mampu menyebabkan kerusakan hepar atau cedera hepar akut idiosinkratik tetapi tidak ada kasus yang meyakinkan dalam literatur medis. Peresepan obat terbanyak yaitu kategori $\mathrm{X}(32.2 \%)$. Kategori ini merupakan kategori yang tidak diketahui apakah ada kerusakan hepar. Hal ini karena penggunaan obat yang masih jarang digunakan dalam pengobatan klinis. Mungkin ada informasi yang tidak memadai tentang risiko kerusakan hepar untuk masuk ke dalam salah satu kategori, sehingga dicirikan sebagai "tidak diketahui" [13].

Penggunaan obat penginduksi hepar pada pasien sirosis perlu diperhatikan melihat bahaya yang ditimbulkannya. Berdasarkan hasil penggunaan obat yang berisiko hepatotoksik terdapat beberapa obat yang menjadi terapi utama pengobatan sirosis. Obat-obatan tersebut tidak harus dihindari, namun cukup dilakukan pemantauan dan penyesuaian dosis yang tepat [10].

Pasien sirosis memiliki fungsi hepar yang tidak berfungsi dengan baik sehingga pemberian obat hepatoprotektor dapat membantu melindungi atau mengurangi resiko kerusakan hepar. Persentase pasien sirosis yang menggunakan obat hepatoprotektor sebesar $86.1 \%$. Berdasarkan Tabel 4 penggunaan obat hepatoprotektor yang diterima pasien sirosis sebanyak 31 obat dari 29 pasien dimana ada 2 pasien yang mendapatkan 2 jenis obat hepatoprotektor. Persentase penggunaan obat hepatoprotektor yang paling banyak digunakan adalah curcuma (55,6\%). Menurut Haryanti dkk membuktikan bahwa ramuan jamu yang mengandung curcuma dapat berfungsi sebagai hepatoprotektif yang diberikan bersama dengan parasetamol berupa penghambatan kenaikan kadar Serum Glutamic Pyruvic Transaminase (SGPT). Serum Glutamic Oxaloacetic Transaminase (SGOT). Malondialdebyde (MDA) dan Alkaline Phosphatase (ALP) serta gambaran sel hepar secara histopatologis yang lebih baik dibandingkan kontrol [19]. Mekanisme hepatoprotektif curcumin melalui penghambatan proses inflamasi, penangkapan stress oksidatif, dan penurunan aktivasi hepatic stellate cells (HSC). Penghambatan aktivitas HSC melalui meningkatkan regulasi ekspresi dan stimulasi signaling gen PPAR-y. Curcumin menekan proses inflamasi sel hepar melalui penurunan kadar sitokin inflamasi termasuk interferon-y, TNF- $\alpha$, dan interleukin [20].

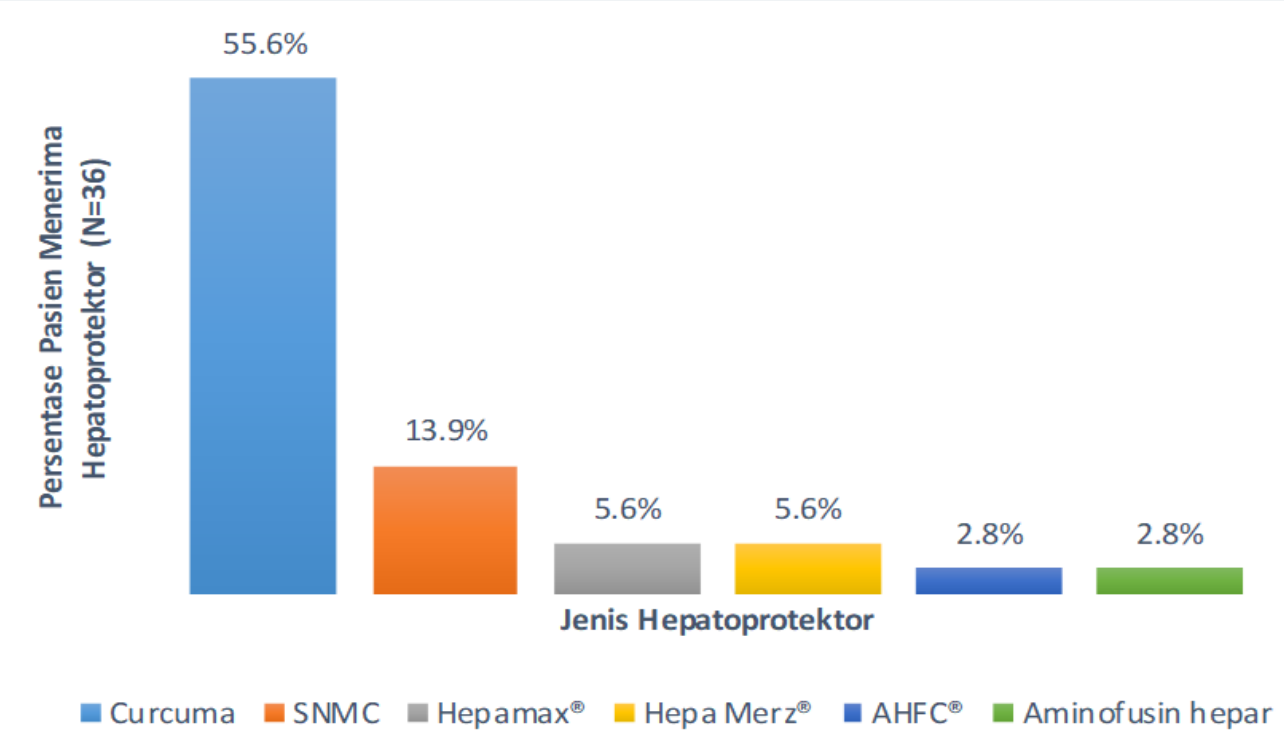

Gambar 1. Persentase peresepan hepatoprotektor pada pasien sirosis 


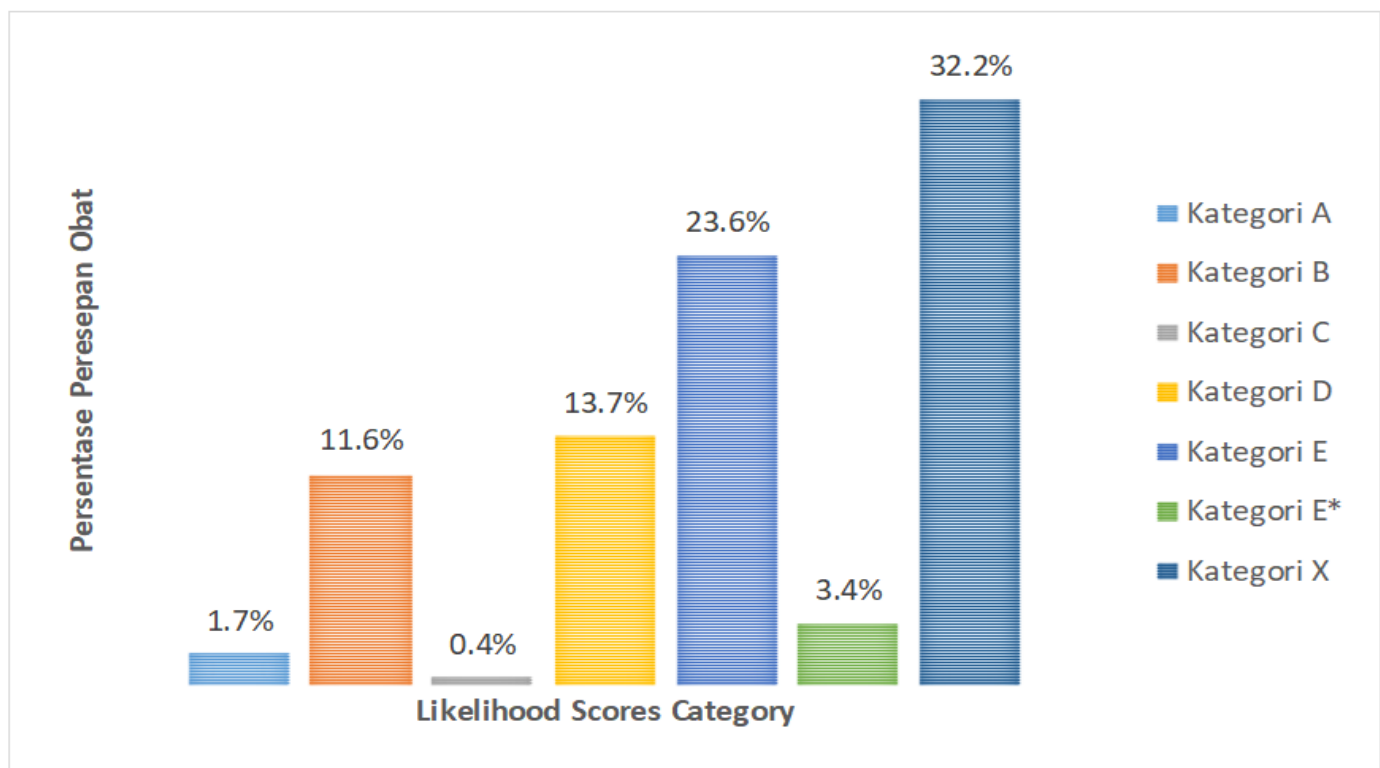

Gambar 2. Persentase penggunaan obat berisiko hepatotoksik berdasarkan likelihood score

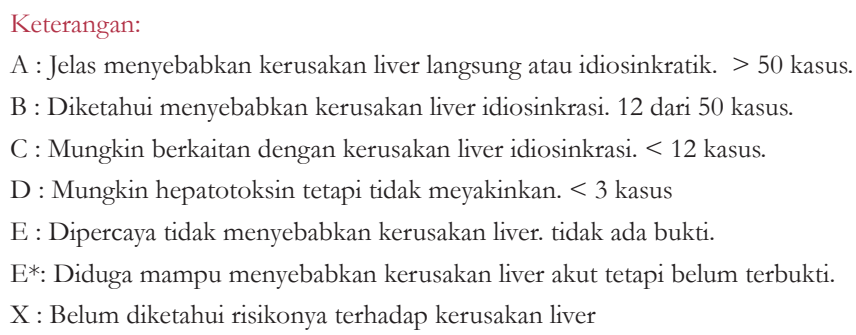

Hepa-Merz ${ }^{\circledR}$ merupakan obat yang mengandung ornithine L-aspartate. Menurut Goh et al. L-ornithine L-aspartate tidak yakin dapat mencegah atau mengobati ensefalopati hepatik pada orang dengan sirosis. Informasi lebih lanjut diperlukan sebelum nilai L-ornithine L-aspartate untuk mencegah dan mengobati ensefalopati liver [21]. Penelitian Farida, dkk menunjukkan bahwa pemberian injeksi SNMC bermanfaat untuk mencegah perburukan fungsi liver agar tidak terjadi keparahan lebih lanjut tetapi tidak memberikan efek perbaikan pada fungsi liver pada pasien sirosis [22].

Pemberian hepatoprotektor tidak dicantumkan pada tatalaksana terapi sirosis dalam standar pelayanan medik rumah sakit. Kenyataannya. obat-obat hepatoprotektor terutama diberikan pada pasien yang mengalami peningkatan nilai SGOT dan SGPT [22].

Pemeriksaan fungsi hepar dilakukan untuk mendeteksi adanya kelainan atau penyakit hepar, membantu menengakkan diagnosis, memperkirakan beratnya penyakit, menilai hasil pengobatan, membantu mengarahkan upaya diagnostik selanjutnya serta menilai prognosis penyakit dan disfungsi liver $[23,24]$.

\section{Kesimpulan}

Jumlah peresepan obat yang diterima oleh pasien sirosis rawat inap di RSUD dr. Soedarso Pontianak Kalimantan Barat tahun 2017 yang berpotensi DILI berdasarkan Likelihood Score kategori A, B, C, D, E, E* sebanyak 127 obat dari 233 total peresepan obat (54,4\%). Jenis obat berisiko hepatotoksik yang paling banyak digunakan dari masing-masing kategori adalah sistenol® (A), ranitidin (B), cetirizin (C), spironolakton (D), furosemid $(\mathrm{E})$, dan ketorolac $\left(\mathrm{E}^{*}\right)$. Persentase peresepan obat berdasarkan Likelihood Score kategori $\mathrm{A}=1,7 \%$. $\mathrm{B}=11,6 \% . \quad \mathrm{C}=0,4 \% . \quad \mathrm{D}=13,7 \% . \quad \mathrm{E}=23,6 \% . \quad \mathrm{E}^{*}=3,4 \%$ dan $\mathrm{X}=32,2 \%$. Total persentase obat berpotensi DILI (kategori A, B, C, D, E, E*) sebanyak 54,4\%.

\section{Referensi}

[1] European Association for the Study of the Liver. EASL clinical practice guidelines on the management of ascites. spontaneous bacterial peritonitis. and hepatorenal syndrome in cirrhosis. 2010; 53: 397 417.

[2] Sanchez W. Talwalkar JA. Liver Cirrhosis. Mayo College of Medicine: San Antonio; 2012. 
[3] Cahyono. SB. Hepatitis B. Yogyakarta: KANISIUS; 2010.

[4] Kementerian Kesehatan Republik Indonesia. Riset Kesehatan Dasar 2014.

[5] Nurdjanah S. Buku Ajar Penyakit Dalam Edisis Ke-5 : Sirosis. Pusat Penerbitan Departemen IImu Penyakit Dalam Fakultas Kedokteran Universitas Indonesia. 2009: 668-673.

[6] Tambunan A. Karakteristik Pasien Sirosis di RSUD dr. Soedarso Pontianak Periode Januari 2008 - Desember 2010. Pontianak: Fakultas Kedokteran Universitas Tanjungpura. 2012.

[7] Simamora CT. Hubungan Komplikasi. Skor Child-Turcotte. dan Usia Lanjut Sebagai Faktor Risiko Kematian pada Pasien Sirosis di RSUD dr. Soedarso Pontianak Tahun 2008-2012. Pontianak: Fakultas Kedokteran Universitas Tanjungpura. 2013.

[8] Sonderup MW. Drug induced liver injury: drug-induced liver injury is a significant cause of liver disease. including chronic liver disease. Continuing Medical Education. 2011. 29(6): 2442-2446.

[9] Russmann S. Kullak-Ublicky. Currebt Concepts of Mechanisms in Drug-Induced Hepatotoxicity. Current Medicinal Chemistry. 2009. Tersedia dari: http://www.ncbi.nlm.nih.gov/sites/entrez.

[10] Hikmah E.N dan Mutmainah N. Penggunaan Obat-Obatan Penginduksi Penyakit Liver Terhadap Pasien Gangguan Fungsi Liver Di Rumah Sakit X Surakarta Tahun 2013. Skripsi. Universitas Muhammadiyah Surakarta. 2014.

[11] Cahaya N. Safitri A R. Mutia. Evaluasi Obat-Obatan Berpotensi Hepatotoksik Pada Pasien Dengan Gangguan Fungsi Hepar Di Ruang Rawat Inap RSUD Ulin Banjarmasin. Jurnal Pharmascience. 2014; 1 (2): 16-26.

[12] Tajiri K dan Shimizu Y. Practical Guidelines for Diagnosis and Early Management of Drug-Induced Liver Injury. World J Gastroenterol. 2008; 14(44): 6774-6785.

[13] US National Institute of Health. LiverTox: Clinical and Research Information on drug-Induced Liver Injury. United States. National Library of Medicine. Tersedia dari: https://LiverTox.nih.gov/.

[14] Guy J and Peters MG. Liver Disease in Woman: The Influence of Gender on Epidemiology. Natural History. and Patient Outcomes. Gastroenterology and Hepatology. 9.10. 2013.

[15] Oktaviani I. Aspek Farmakokinetik Klinik Obat-Obatan yang Digunakan Pasien Sirosis di Bangsal Interne RSUP Dr. Djamil Padang Periode Oktober 2011-Januari 2012. Laporan Penelitian. Padang. 2012.
[16] Lotter H. Helk E. Bernin H. Jacob H. Prehn C. Adamski J. Roldan NG. Holst O. and Tannich E. Testosterone Increases Susceptibility to Amebic Liver Abscess in Mice and Mediates Inhibition of IFNY Secretion in Natural Killer T Cell. PloS One. 2013;8(2).

[17] Deng X. James P. Luyendyk. Patricia E. Ganey and Robert A. Inflammatory Stress and Indiosyncratic Hepatotoxicity: Hints From Animal Models. Pharmacological Reviews. 2009; 61(3).

[18] Ditjen Bina Kefarmasian dan Alat Kesehatan. Jakarta: Pharmaceutical Care Untuk Penyakit Liver: Departemen Kesehatan Rl; 2007.

[19] Haryanti S. Ratnawati G. Dewi APK. Laporan Penelitian: Studi Praklinis Potensi Hepatoprotektif Ramuan Jamu (Rimpang Temulawa. Rimpang kunyit. Dan Herba Jombang). Tawangmangu: B2P2TOOT; 2012.

[20] Fu Y. Zheng S. Lin J. Ryerse J. Chen A. Curcumin Protects The Rat Liver From CCl4-Caused Injury And Fibrogenesis By Attenuating Oxidative strees and suppressing inflammation. Mol Pharmacol. 2008; 73(2): 399-409.

[21] Goh E. Stokes CS. Sidhu SS. Vilstrup H. Gluud L. Morgan MY. L-Ornithe L-Aspartate For People With Chronic Liver Disease And Hepatic Encephalopathy ( Poor Brain Functioning).

[22] Farida Y. Andayani TM. dan Ratnasari N. Analisis Penggunaan Obat Pada Komplikasi Sirosis. Jurnal Managemen Dan Pelayanan Farmasi. 2014; 4(2).

[23] Hall P. Johnny C. What is the Real Fungtion of the Liver 'Function" Test. Ulster Med J. 2012; 81:30-36.

[24] Suryaatmadja M. Pemeriksaan Laboratorium Uji Fungsi Liver. Buletin ABC. 2009; 11: 2-8.

[25] Kementerian Kesehatan Republik Indonesia. Pedoman Interpretasi Data Klinik. Riset Kesehatan Dasar 2014. Tersedia dari: https://www. researchgate.net/publication/303523819_Pedoman_Interpretasi_ Data_Klinik.

[26] Wojtowicz. Ewa J. Elzbieta B. Violetta S. Testosterone. Estradiol. Progesteroneand Sex Hormone Binding Globulin (SHBG) Blood Serum Levels in Men With Acute Viral Hepatitis A or B. Med Sci Monit. 2007; 3(5): 686-691. 